\title{
History, architecture, and heritage in the railway station of Almería (1892-2017)
}

\author{
Domingo Cuéllar

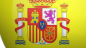 \\ PhD Historian. Grupo RENFE. Madrid [Community of Madrid] Spain. <cuellar.domingo@hotmail.com>

\section{Aurora Martínez-Corral} \\ PhD Architect. Part-time University Professor. Universitat Politècnica de València (UPV). Valencia \\ [Valencian Community] Spain. <aumarcor@csa.upv.es>
}

\begin{abstract}
Most of the life cycle of the railway infrastructures is singularly long-lived. Thus, in the case of the reference buildings, as is often the way with the travellers buildings, their use far exceed the century. In addition, many of these stations were born in the 19th century with a symbolic representation load with which they have not still parted. This is the reason why many analyses referred to railway heritage are emotionally charged. In our study of the case, the railway station of Almería, 125 years after its construction, the building remains without use since in 2000 was replaced by the attached intermodal station, which has led at present to an intense debate on his preservation and reuse. It is a building that, despite possessing singularities and architectural relevancies of great interest, the process of patrimonial protection is unfinished being a clear threat to the integrity of the building. As it is exhibited in the text, despite the modesty of the railway company that built it, the building stands out on most of the principal stations of Spain. We do a brief managerial note of the company that entrusted its construction and later we study closely the architectural program of the building, the different interventions carried out and the current situation of the heritage protection.
\end{abstract}

\section{Keywords}

Railway Architecture. Eclecticism. Architectural Restoration. Heritage Protection, Almería (Spain). 


\section{Introduction}

In the researches made on the architecture of the railway stations built during the nineteenth century, two ideas have symbolized the function exercised from that moment by these new buildings in the main cities: on the one hand, they were constituted as the new entrance doors and departure to the city and, also, they became the new cathedrals of the contemporary world (Meeks, 1995).

When they had already been demolished, or in the process of being, most of the urban walls and the cycle of construction of the great religious temples had ended, the Industrial Revolution brought an unprecedented urban change in which the railway not only altered the form of cities but also their content, redistributing spaces and changing, in many cases, the hierarchy of some over others (Sobrino, 2008).

From that moment the cities had a new central element that should look as significant as it was the medieval cathedral with the same strategic role of the medieval gates of regulating the movement of people and goods. Hence the singular role played by the architecture of these buildings which were built out of catalog to highlight their uniqueness with respect to the standardization of the rest of buildings of the railway line to which it belonged. Realizing also the circumstance that many of these stations were the end of these lines, reinforcing its administrative and economic hierarchy on the urban environment (Aguilar Civera, 1988, pp. 183-205).

Graphic 1. Current situation of the travellers building of the historical Spanish railway stations according to the period of construction overlapped to the broad and narrow track kilometers built in each period.

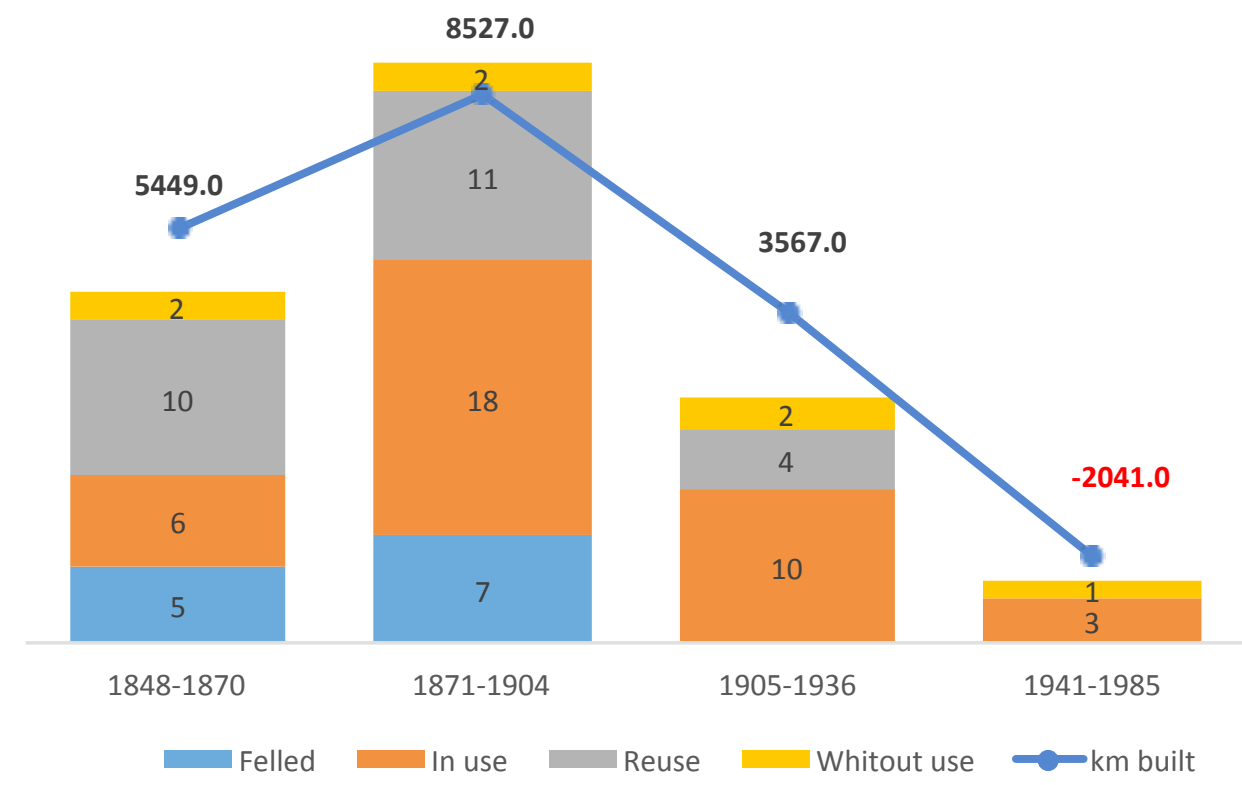

Source: own elaboration.

This process is virtually universal and found only some variations, from some places to others, based on the chronology of the railway construction and the particular conditions of each country. In the Spanish case, there are obvious similarities with other neighbour countries, but our railway cycle has a temporary offset of ten to twenty years and our volume of activity, due to the lower economic development and the scarce population, also has conditioned the importance of these railway buildings.

In this way, from the studies already carried out on the construction of the railway stations in Spain $^{1}$ and the periodization of the development of the Spanish rail system ${ }^{2}$, it is found a clear

\footnotetext{
${ }^{1}$ Among the most relevant, we point to López García, 1986; Aguilar Civera, 1988; González Fraile, 1997; MartínezCorral, 2017.

2 Comín, Martín Aceña, Muñoz Rubio, \& Vidal Olivares, 1998; Cordero \& Menéndez, 1978; Cuéllar, 2017.
} 
correlation between the development of the network and the construction of the definitive travellers buildings of the main stations (Graphic 1$)^{3}$.

We have to bear in mind, however, that during the construction of the first lines, many temporary buildings and piers were erected to lighten the construction deadlines and costs. This meant that some stations that were already in service during the first railway impulse had not built their definitive station until a few years later. From 1870, however, the definitive stations were already lifted, and changes only occurred when extensions or new projects derived from the needs of the service were necessary 4 .

The data shown in Graphic 1 offer an image of stability in use of most of the Spanish stations. Thus, of the 81 buildings studied, 41 remain in railway use (51\%), 21 have been destined for other uses (26\%), 12 have been demolished (15\%) and only 7 are in disuse (9\%). Unfortunately, Almería railway station (Illustration 1) is one of these few cases in disuse. It is not, therefore, usually the idle situation of this type of buildings, at least in large cities. The lack of use is indicated as one of the great threats of industrial heritage and even more so when it is prolonged in time. (Cano, 2007).

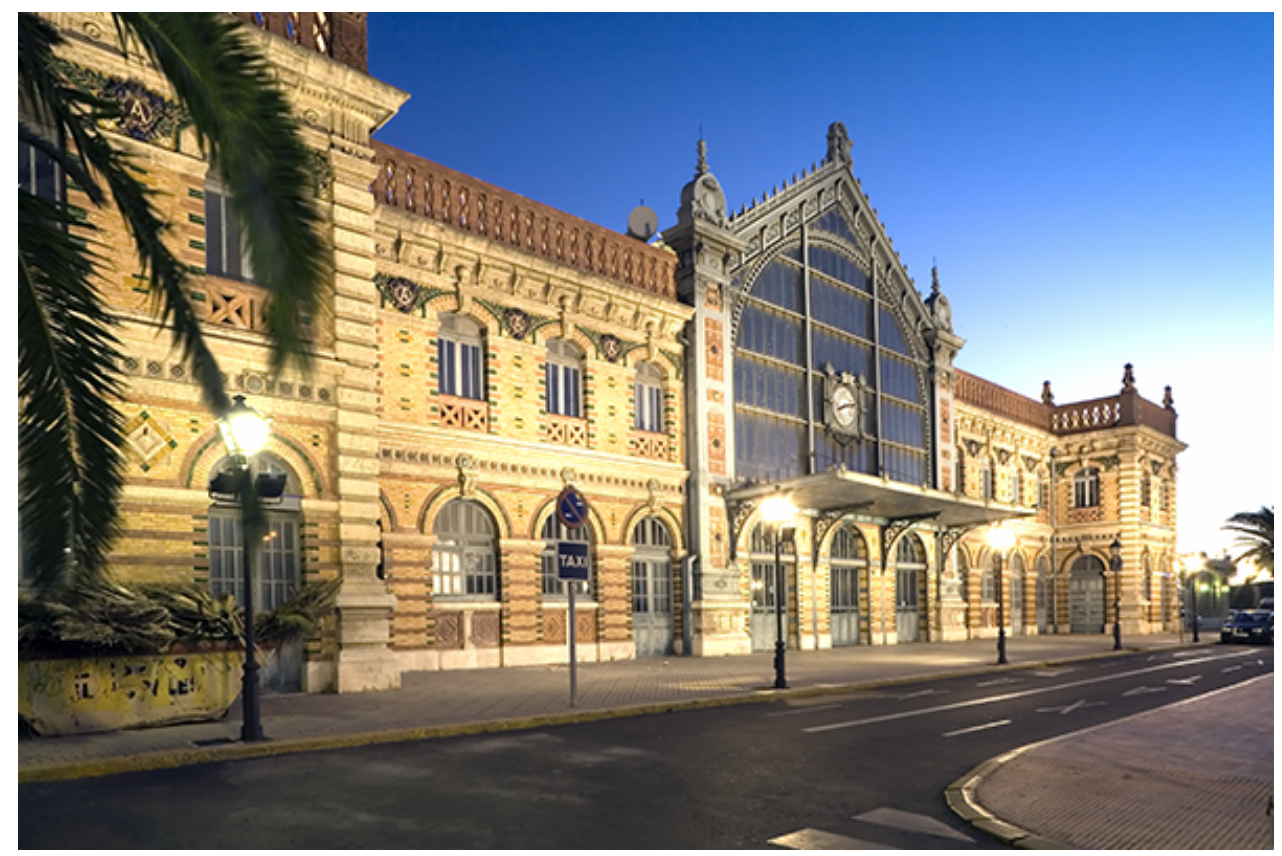

Figure 1. View of main facade of Almería Railway station.

Source: Spanish Railway Foundation, 2006; Picture: José Morón.

Regarding the rest of the Spanish stations studied without defined use, León and Zaragoza Portillo, have arrived at this situation in very recent dates, after the construction of the new highspeed lines. For instance, the old Tutela-Bilbao railway station in Miranda de Ebro has already been rehabilitated for cultural use, but is still pending operation; the building of Narciso Clavería in Algodor (Illustration 2) is in a serious situation after the closure of the Toledo line in 2005; and, finally, the gigantic building of the international station of Canfranc (Illustration 3), underused during the years in which the line was in service to Pau (France) and barely used since the closure of this international line in 1970, is actually a white elephant object of a debate as intense as complex.

\footnotetext{
3 We included in this group of main stations, province main cities or those that had a special project in their construction, given the importance of the locality, both in the case of wide and narrow track railways. In total, we have identified 81 buildings that were built between 1856 (Tarragona) and 1972 (Zaragoza Portillo).

${ }^{4}$ Some examples of travellers buildings built during this second railway impulse: Santiago (1873), Gijón (1874), Salamanca (1877), Portbou (1878), Madrid-Delicias (1880), Alicante-Benalúa (1887), Jaén (1890), Soria (1892) or Almería (1895).
} 


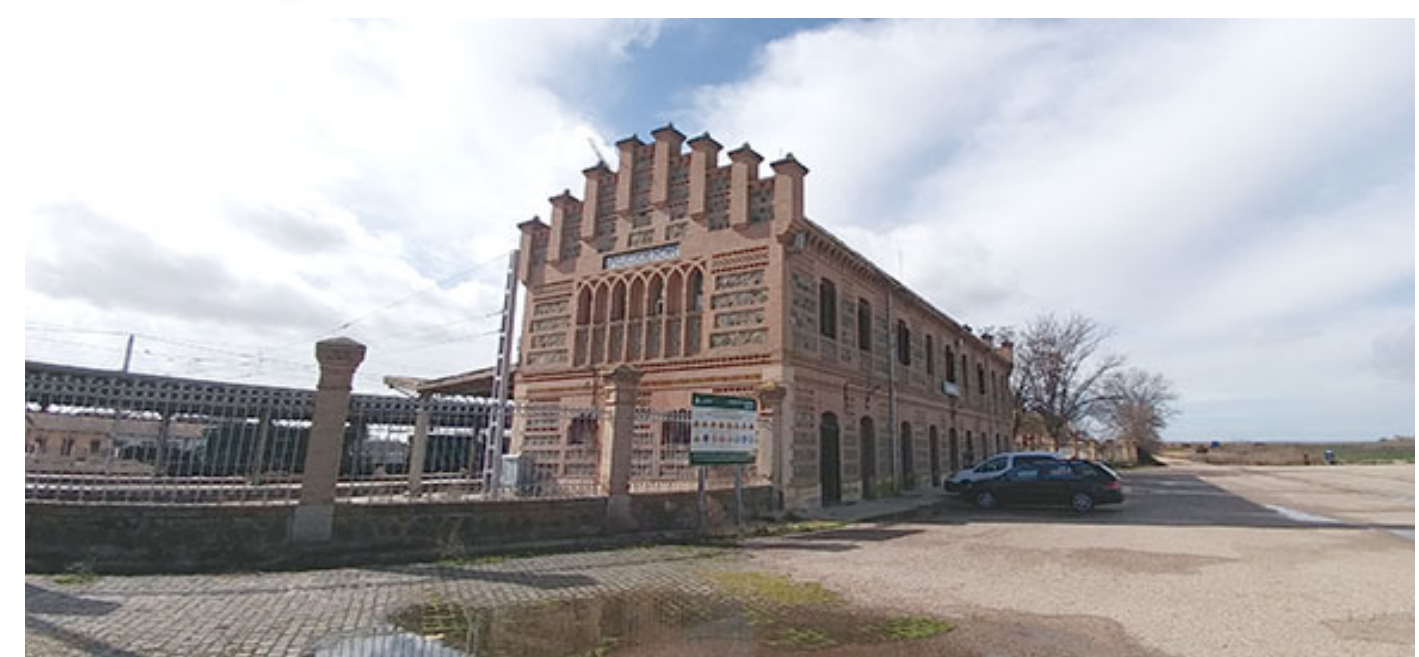

Figure 2. View of Algodor (Toledo) Railway station. Source: Martínez-Corral, 2018.

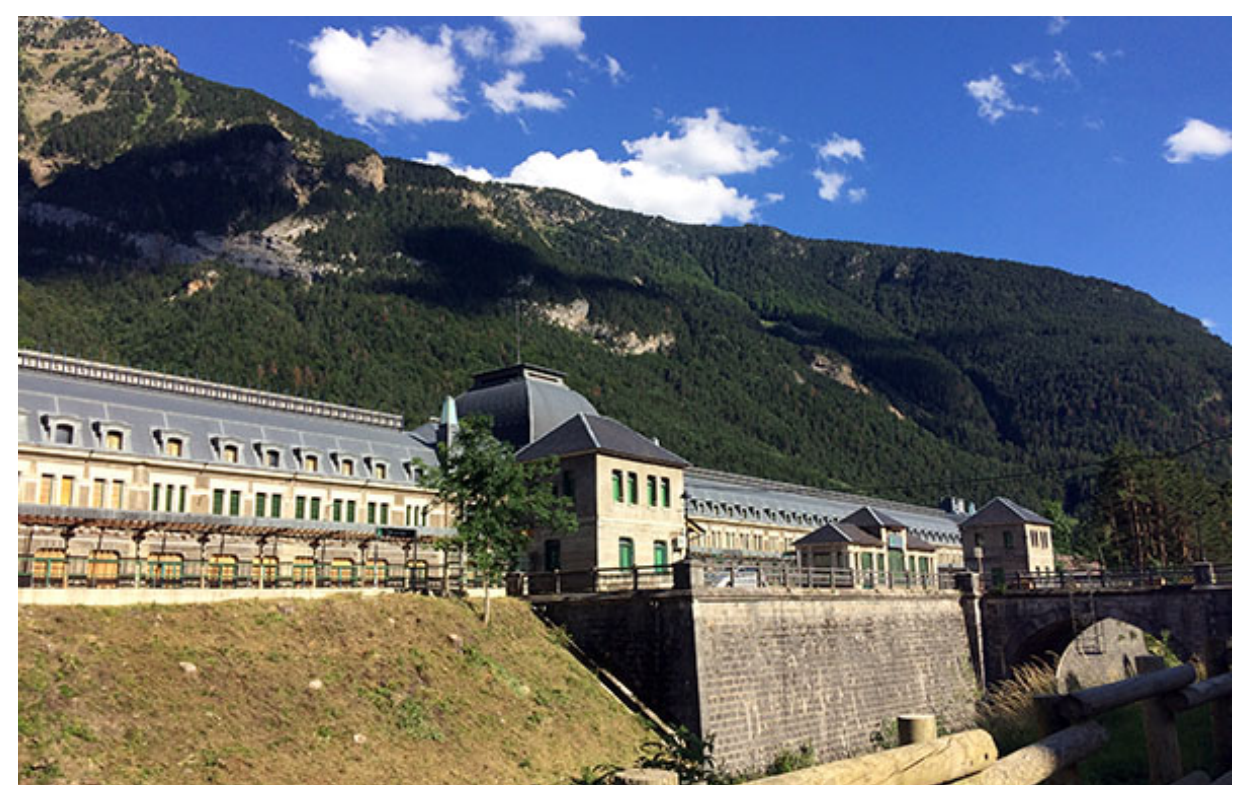

Figure 3. View of Canfranc (Huesca) Railway station. Source: Martínez-Corral, 2017.

This text has, therefore, as main goal the integral study of the travellers building of the Almería railway station, from its business origins, the construction and operation of the passenger building, the renovations carried out, and, finally, to the current situation about the heritage protection. Although there are previous works that highlighted the architectural interest of the building, we believe that it is now important to make an integral contribution that covers, from different views, the story from its construction to the current situation. Our objective is the dialogue between the contributions of economic history, architecture and industrial archaeology to build a discourse that contributes to the preservation and proper use of the building.

The main sources of research have been original files on the preserved building and the literature up to now on this case which contextualizes the set of existing literature on railway stations, especially in Europe. Equally, we worked on the ground, on the outside of the building - it was not possible to visit indoors - and analyzed different historical images of the building since its construction until now to observe details and undocumented modifications.

After this introduction, the structure of the article comprises a first section with a general reference to the historical framework of the railway in Almería. A second one containing a detailed study of the architectural features of the building exploring some formal and stylistic issues not studied before. The next chapters include the main renovations carried out in the building until today and the attempts carried out by the Administration for the building heritage protection, still unfinished, ending with some conclusions on its patrimonial status and use. 


\section{The historical framework of the railway in Almería}

The Linares-Almería railway line was one of the last of the Spanish network to be built. In particular, the completion of the section from Guadix to Almería took place in 1895 and the link with the general line in Baeza-empalme was held in March of 1899. At that time only the main cities of the Spanish provinces Soria and Teruel did not still have railway service (Illustration 4).

The delay in the arrival of the railway to Almería was attributed to the lack of interest of foreign investors, the main financiers of railway construction in Spain during the 19th century, also because it was a peripheral railway line passing through territories with a very complex orography and even with scarce demography. The publication of the 1870 law made the construction of this type of railway more viable since it granted a guaranteed subsidy that could suppose an incentive for these lines. Even so, the concession was delayed for a few years and only the appearance of mining interests gave the definitive impulse to the construction of the line in the last decade of the 19th century (Cuéllar \& Sánchez Picón, 1999).

This delay put in the head of the project a singular businessman who was the promoter of the building and the owner of the company until his death. This man was Ivo Bosch Puig (1852-1915), who began as a stockbroker in Barcelona and, only with 25 years, settled in Paris developing investment business with the major financial houses of the time. His return to Spain (maintaining though for many years its Champs Elysees Hotel) happened in 1881 when he got involved in the business management of the Madrid General Bank and in the Linares to Almería railway line, which had been several years without anyone interested in its construction (Cuéllar, 2011).

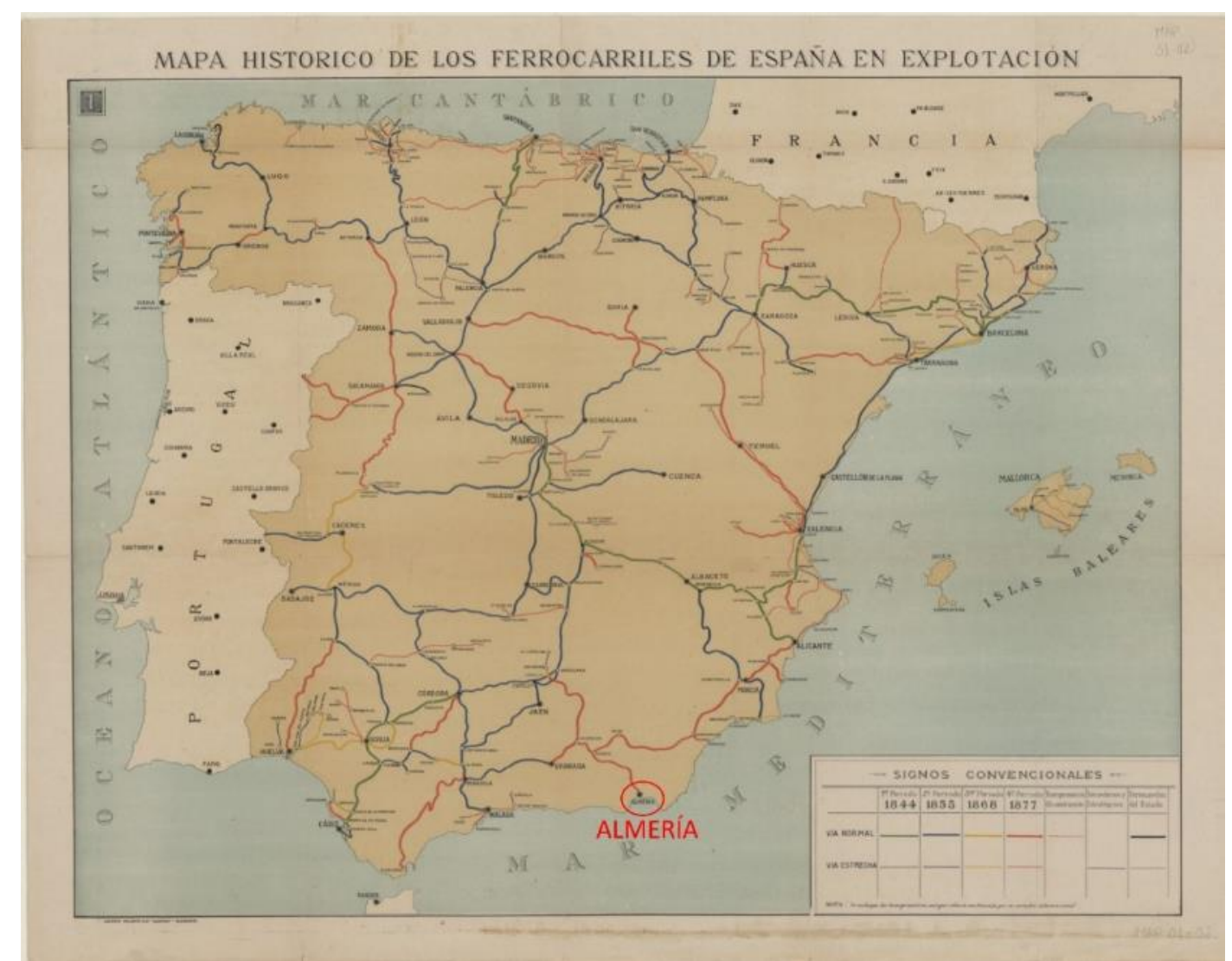

Figure 4. Map of the Spanish railway lines (1918). Source: Historical Railway Archive, document MAP-01-02.

The business forms of Bosch took special care of their image with the intention of impressing their partners and customers, being political relationships at the highest level the axis of his strategy. This is reminiscent of the ways of another Spanish railway entrepreneur, José de Salamanca (1811-1883), who had starred in the glare and decline of the railway in Spain during the decades from 1850 to 1870 (Broder, 2012). 
The Spanish Southern railway company was made in the image of the strong personality of its main shareholder, Mr. Bosch, who made that almost all the actions undertaken by the company had something of exaggerated pursuing goals and achievements hardly expected such a modest company.

Thus, among other concerned issues, we can remember that this railway company had some engineers and lawyers who achieved great popularity in the following years such as José Moreno, Earl of Fontao (later director general of North railway company and RENFE ), Luis Olanda (later director of exploitation in MZA), or Juan Cervantes (later director of the legal service in MZA) in addition to having a long list of politicians who gave renown to the company as Laureano Figuerola, General Valeriano Weyler, Antonio García Alix or José Cárdenas, all ministers in the Restoration period (Cuéllar, 2003): Moreover, Spanish southern company was in 1912 the company that carried out the start-up of the first electrified railway line in Spain, a first-class technological milestone for which it was supported by the Swiss company Brown-Boveri (Cuéllar, 2003).

It was then logical, that the company conceived as something special the proposal of the construction of the travellers building since it should be representative of the category, identity, and power of the company. Therefore, resources were not spared in the construction, hiring one of the most important companies in Europe in the railway sector, the French company Fives-Lille. This, by special order of Bosch, conceived a building of "great architectural character". The definitive project was sent to its approval by the General Direction of Public Works in Madrid in 18925.

The construction of the building, as we have said, was carried out by the company Fives-Lille, but the authorship of the project is attributed to the French architect Laurent Farge 6 , as it is in an inscription on the main facade next to the entrance to the west tower of the building. In addition, different references of other authors, information inserted in the press of the time together with the participation of this architect in the universal exhibition of Paris in 1889 and the observations on his architectural style, make believe that the identification of the authorship is the correct one despite the plans are not signed by him, but by the owners of the company responsible for the construction of the line as usual (Cuadros Trujillo, 2015).

It is also important to highlight that the new travellers building was located outskirts, as was typical in the railway implementation in most of the Spanish cities. Only in few cases, it penetrated the historic city looking to avoid expensive works and facilitating the development of the nineteenth-century city expansions 7 . This also happened in the city of Almería, but this external position required an urban intervention that consisted in the design by the local architect Trinidad Cuartara of a promenade, called "Paseo de la estación", which connected the historic city with the expansion areas that began to develop around the railway station in those years ${ }^{8}$.

\section{Architectural analysis of the building}

\subsection{Regarding typology}

The typology of the Almería station is peculiar since it does not adopt the typical solutions used in other Spanish stations, most of which, especially passing stations, used the type of one building on one side of the tracks ("I" shaped stations) or the "U" shaped specially for terminal stations typical in the big cities (Navascués \& Aguilar Civera, 1980, p. 162). Nor does it adopt the typology devised by Brunel consisting of two side by side buildings on one side of the tracks so that any traveler, either for arrivals or departures, had to cross the tracks. This required a track crossing that was useful in the few cases where this typology was used, being only effective in

\footnotetext{
5 Historical Railway Archive (onwards, AHF), A-121-01, Travellers building of Almería railway station. The railway line from Linares to Almería (1892).

${ }^{6}$ Farge or Fargé, according Sobrino, 2008, p. 877, was resident in Spain in those years.

${ }^{7} \mathrm{~A}$ broad analysis of this issue is in Santos y Ganges, 2007. About the specific case of Almería, see Santos y Ganges, 2008, pp. 734-735.

8 See information on this initiative in "La Crónica Meridional", 26-01-1898.
} 
cases of reduced railway traffic. It was a typology specially designed for those populations where the location of the station is tangential to it, leaving the entire urban nucleus only on one side (Meeks, 1995, pp. 30-31).

Similarly, it does not follow the approach of L. Reynaud where the first-class stations were materialized with a single building on the head, the second class with two buildings (arrivalsdepartures) on both sides of the tracks or the third class, with two "L" shaped buildings, one on the head and one on one side of the track.

Thus, the typology of Almería station would be a combination of both solutions being a "U" shaped timidly expressed, with small wings oriented towards urban space on one side of the track. Although the station was terminal the railway line was continued to the nearby Almería port and probably, that is the reason of the peculiar building shape.

\subsection{Regarding functionality}

As regards functionality, the building has two floors except for the hall which is developed on a monumental scale. The monumentality may be due to two reasons: on one hand, the intentional effect of monumentality, better called pseudo monumentalism, as a representation of the company power reflected even in the main facade with the giant order of the pilasters flanking the central body of the building. On the other hand, the intention of showing a sincere language according to the properties of the new material (steel) that allows big lights and heights and, consequently, to achieve monumentality without intending it. That is the real monumentalism, the one which is achieved in an unconsciously way (Sostres, 1951, pp. 24-27). In summary, in Almería railway station it is possible that both are intended: the intended effect of monumentality, but also the desire to show the capabilities of new material as a symbol of technology and constructive modernity.

It is noteworthy that this travellers building gives great prominence to the departure hall which, in addition to occupy the most prominent position in the plant, is projected with twice the space as the arrivals located on the left wing of the ground floor. Thus, regarding the functionality of the station projected originally, on the ground floor, in addition to the aforementioned places, there is a luggage counter in the departures lobby and the ticket office falling to it. On the right wing, are arranged without public access, the offices of employees, chief of station, commissioner and the staircase to access the houses located on the top floor. The public telegraph, located in this wing, is accessed from the outside by the main facade. Basically, the distribution of this wing is based on offices connected to each other without the existence of a corridor since they have independent access from one of the two facades.

The left wing, however, is entirely public access. It is entered from the departures hall by means of a corridor that leads to the waiting rooms of 1st, 2nd and 3rd class, consecutively. All these spaces have direct access from the main platform and from the main facade. Regarding this separation by classes, it was already established in Euston station (1835-1839) and was adopted in the stations of first category or special category (Meeks, 1995, p. 32).

In this sense, therefore, the station of Almería is equated to a first-class station as it appears in the site plan of the original project, even though Almería did not have the consideration of a relevant settlement or railway core9. This fact is peculiar because cities of a similar number of inhabitants and railway traffic do not have traveller's buildings as representative as the one that concerns us.

Finally, the arrivals baggage service is in the extreme part of this wing also with access from both facades in connexion with a staircase to access to the upper floor (Figure 5).

On the upper floor, with the accesses through the staircases located symmetrically at both ends of the building, is located the office area on the left wing and, on the right wing, two dwellings for station staff. The simplest one, projected for an employee, consists of toilet, room, dining room,

${ }_{9}^{9}$ This rating of the stations according to the relevance of the population see in Echenique, 1864, p. 67. 


\section{Labor \& Engenho}

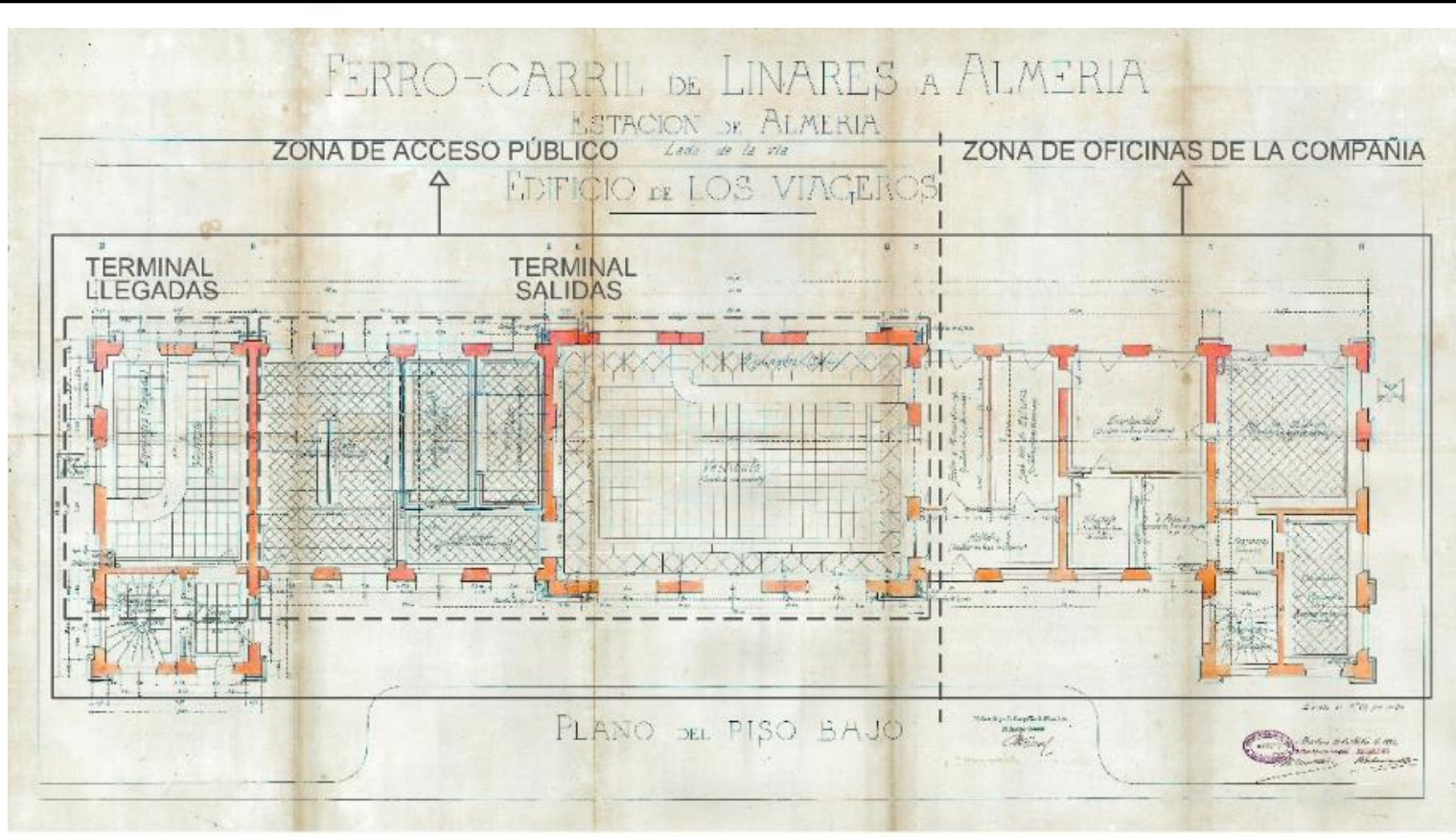

Figure 5. Distribution of uses on the ground floor of Almería station according to the original project of 1892. Source: own elaboration based on AHF, A-121-01.

and kitchen. The other, much bigger, intended for the station manager, has central corridor and rooms falling to the main, lateral and rear facades. This house is composed of a day area next to the lobby with toilet, kitchen, dining room and living room and, night area in the furthest part of the entrance with three bedrooms and a women's cloakroom. In both houses, all rooms connect to each other as well as through the corridor.

\subsection{Regarding composition}

The main facade presents the classical tripartite composition typical at railway stations based on mirror symmetry. The axis of symmetry is emphasized with two key elements: the clock and the name of the city. It also presents the tripartite scheme in the arrangement of the three bodies that form the building: one central, two lateral and two ends, with dimensions respectively of $16 \mathrm{~m}$, $12 \mathrm{~m}$, and $7.5 \mathrm{~m}$. Furthermore, each of the three bodies is dimensioned in a hierarchical manner, giving greater dimension to the most relevant in the composition.

The central body represents the tripartite scheme by metal posts and with the presence of the three main entrances to the building. It also emphasizes the central body, and the main access, changing the scale: human scale for the lateral and extreme bodies with clear distinction of the two levels and "giant order" for the central body. This change of scale is illustrative of the inside distribution, with two floors in the entire building except for the central body - coinciding with the lobby - which is projected at double height as reflected by the facades. In summary, the classic resource of, by means of the facade composition, showing the main distribution of the building.

Analysing the composition, it is discovered the use of golden proportions in the central and extreme bodies of the building.10. The different geometric relations discovered are shown in the figure added (Illustration 6). For instance, the central body is inscribed in a circle whose center is the clock, also emphasizing in this way, the importance of this element.

\footnotetext{
10 The number of gold, golden section or golden ratio or, called in the Renaissance as "Divine proportion" was considered to be the way to create a harmonic work. It is related to existing forms in nature considered pleasing to the eye. It is still in use.
} 


\section{Labor \& Engenho}

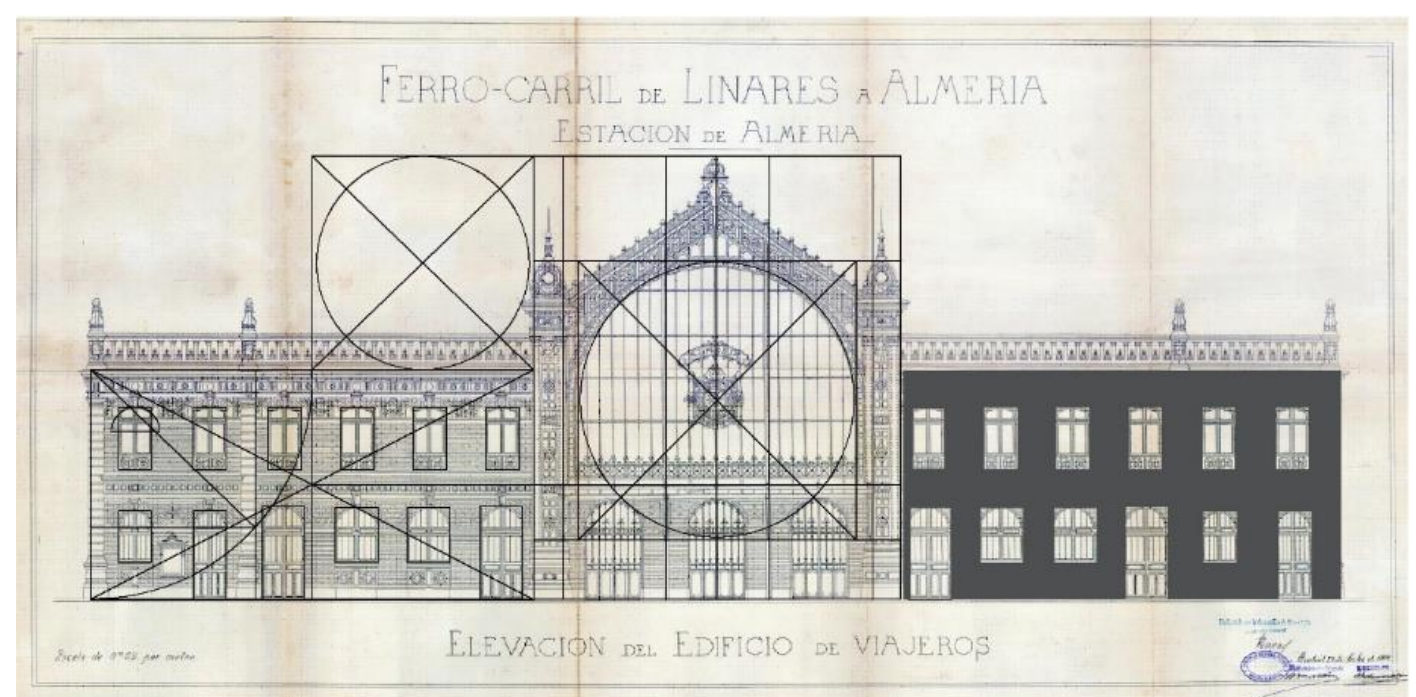

Figure 6. Study of proportions and relationship between massive and hollow in the travellers building of Almería railway station (1892). Source: own elaboration based on AHF, A-121-01.

Another compositional resource to emphasize the central body is the layout, size and number of holes: $2+4+3+4+2$, on the ground floor; and $2+4+1+4+2$ on the upper. Even numbers for lateral and extreme bodies and odd numbers to the central body. Also, the size of the holes is different between those in the lateral and extreme bodies with respect to those of the central body of larger size. With regard to the extreme bodies, they are arranged slightly advanced creating the " $U$ " shape described previously and, despite the fact that the compositional reading of the facades is unitary, the symmetry is strictly broken with the two holes (door-window) arranged at both ends of the building.

The massive-hollow relationship in the lateral and end bodies is balanced highlighting with it the great central hollow. This balanced proportion and good distribution of the hollows is already a resource to achieve monumentality without having to resort to superhuman dimensions (Sostres, 1951, pp. 24-27). The same balance is perceived between the horizontality of the lateral and end bodies and the verticality of the central body.

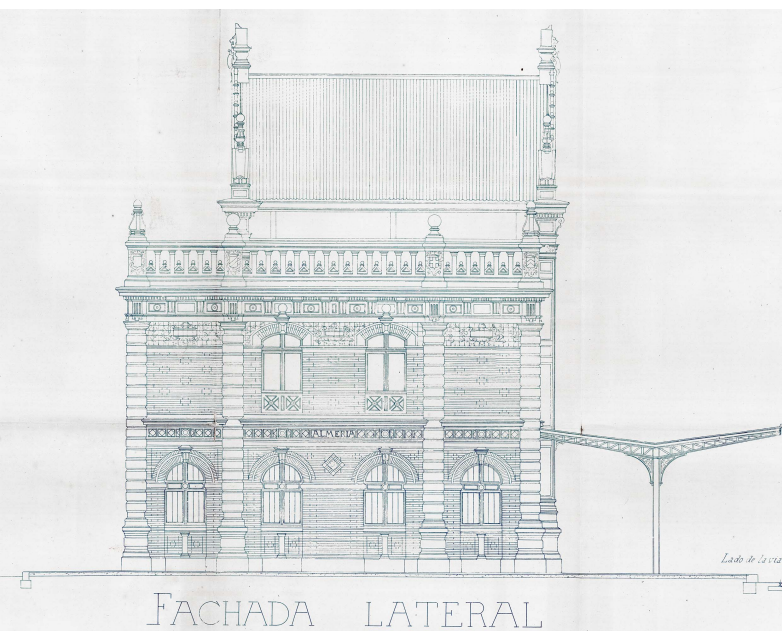

Figura 7. Elevation of the lateral facade. Original project of Almería Railway station. Source: Original project Almería Railway station. AHF, A-121-01.

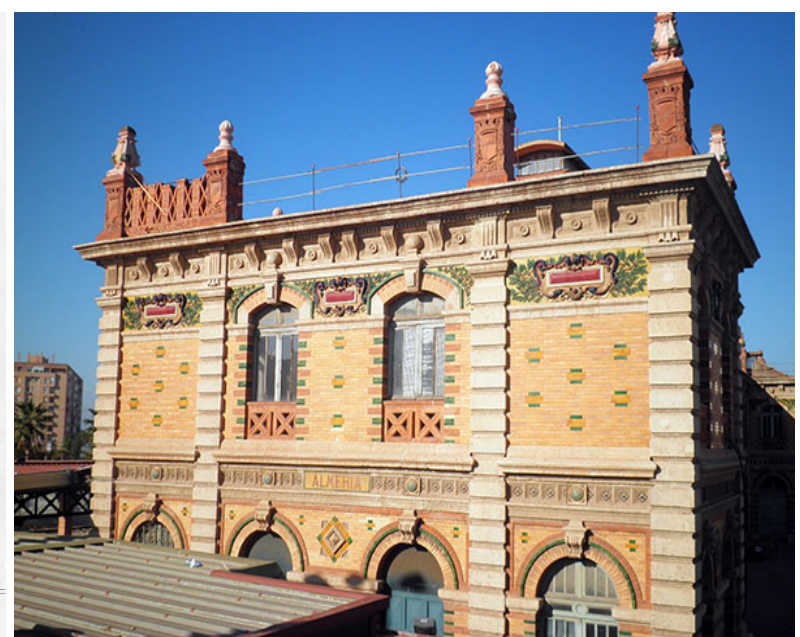

Figure 8. View of lateral facade of Almería Railway station. Source: Morales Medina, 1987.

The compositional scheme described is repeated on the rear and on the lateral facades. The latter show the existence of a central part with hollows in the two floors and two lateral parts delimited by stone corner cushions with hollows topped by Roman arches only on the ground floor. The most notable differences are established by the aspects related to materiality or decoration later discussed. 
The volumetry of the departures lobby reflects the idea of monumentality previously explained. Since the station does not have the typical metal roof covering the space of platforms and tracks, a reminiscent space of it is projected with the peculiarity that this space is the main hall normally treated with another materiality considered superior.

Thus, the aforementioned lobby has an approximate height of $17 \mathrm{~m}$ and the plant are $10 \mathrm{~m}$ of bay for $15 \mathrm{~m}$ of light. This conception of the traveller's lobby made with metal roof insight did not exist in any other Spanish station which is also another singularity of the Almería building. We will see it again, fifteen years later, in the extension of the Barcelona-Vilanova station, built by the architect Demetrio Ribes in 1910.

\subsection{Stylistic and ornamental aspects}

The mixture of styles is shown in the classicism used as the basis of the composition, at the disposal of Roman arches, triangular pediment, baseboards, stone corner cushions, baluster, stone entablatures with its variant of triglyphs and metopes, combined with Moorish style influences such as the brickwork and the cross-shaped handrails. It is also found gothic pseudo pinnacles and beaux-arts style cresting. On the other hand, the analysis of the original project reflects that the original roof baluster was neoclassical style, however, the one that exists today, and which is now in the process of rehabilitation, was done in Moorish style. Later, in the section dedicated to materiality, a hypothesis about this is exposed based on the materials that compound this baluster.

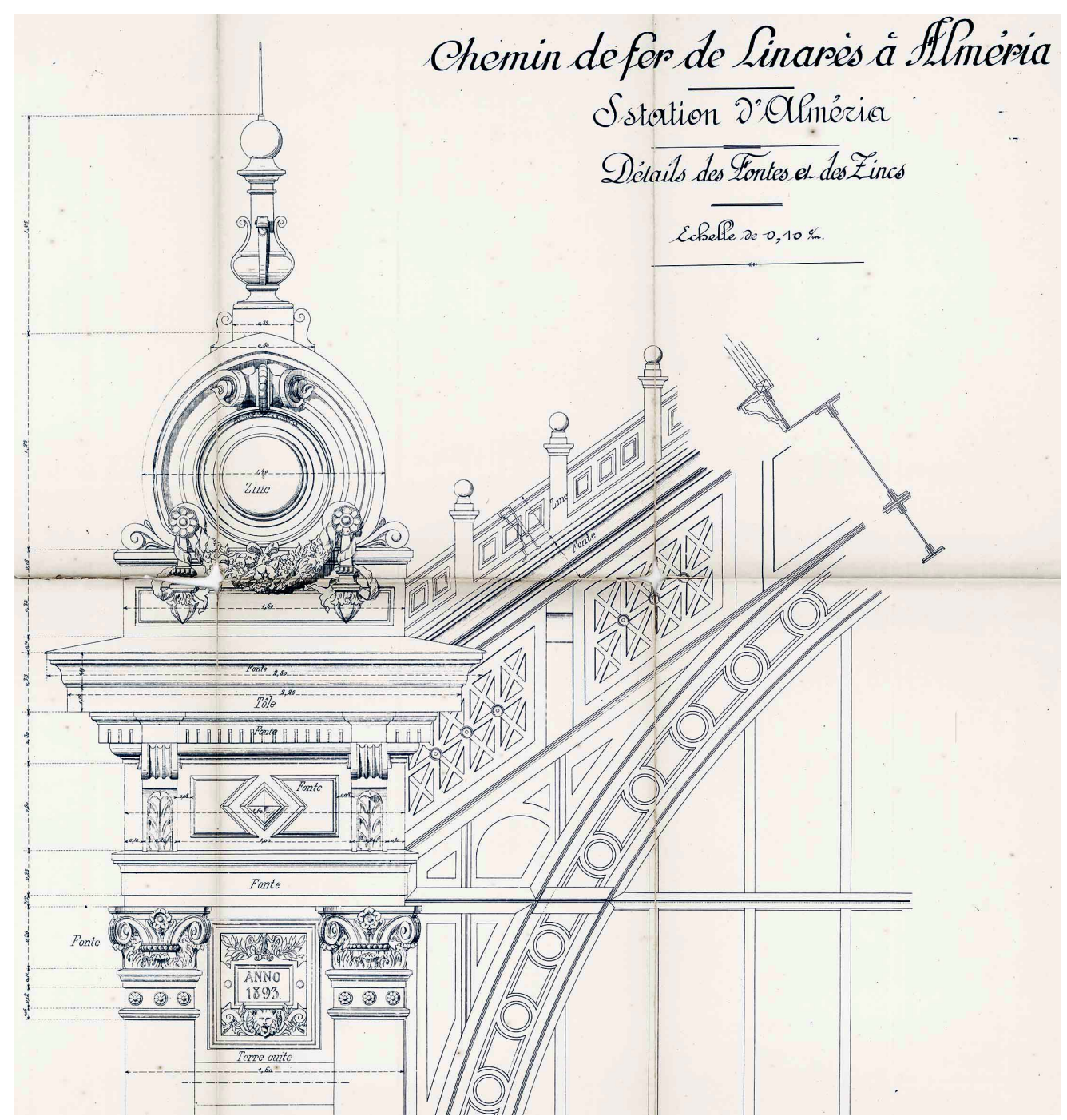

Figure 9. Ornamental detail of the steel pinnacles. Source: Original project Almería Railway station. AHF, A-121-01. 
It is curious the classicist decoration introduced in the novel glass part of the central body. It can be realized the contradiction between the modern material and constructive technology and the traditional decoration. It also highlights the novel insinuation of the metallic structure left in view in the main facade with the columns of giant order flanking the central body, although topped by pseudo-Corinthian capitals (Illustration 9). This suggestion can be interpreted as being of great modernity for the time since the metallic structure, leaving even seen the rivets and reinforcement plates, was generally reserved for the imposing roof covering the space of platforms and roads considering that it was not fine enough to be shown in the lobby and much less on the main facade.

It is convenient to point out that this was a period where architecture is irremediably linked to the styles and traditions of the past. In addition, the large metallic roofs were designed by engineers who usually left them hidden respect to the urban space. In this sense, the author of the project moved away from the apocalyptic discourse of Rada and Delgado that advocated that the architecture of iron could not constitute an own style and industry was going to kill the art, to side with Daly's or Ruskin's theories who advocated a style and language appropriate to the new materials and technologies (Sostres, 1951, pp. 24-27).

The rest of the decoration is introduced in several ways: either forming part of the brickwork by combining natural bricks with green or yellow glazing bricks, or with the inclusion of glazed listels finishing off all the arches; well superimposed on the brick wall using vegetal theme, rosettes or the "A" of Almería, which does not appear in the original project; or, finally, in relief forming part of the limestone friezes, the capitals or the balustrade pinnacles. Ornamental locksmith details appear exclusively on the metallic pediment and on the three main access doors to the station.

In the rear facade, the decoration is reduced to the metallic central body -of identical characteristics to that of the main facade, except for the absence of the name of the city and the clock, the balustrade and the metal railings. It is necessary to emphasize that the sign with the name of the city originally projected over the main facade, never was placed. The edge of the holes is simply made with brick thread without further decoration and neither the entablature nor the arches are decorated.

Special mention should be made of the lateral facades and the architect's delicacy in decorating them as the main facade considering them as an urban facade. In this case, they present a decoration slightly different from that of the main facade, but with the same decorative profusion and combining the same elements. Thus, the decoration of the brick walls is observed, including pieces of alternating green and yellow glazed ceramics and with the inclusion of rectangular pieces in red glazed ceramics wrapped in floral themed decoration.

\subsection{Construction and materiality}

\subsubsection{Dissertation on the use of brick in the railway station}

Steel-brick combination that the station of Almería presents has its origin in France. In the 19th century, walls made by brickwork left in view on the facade, a material with a long constructive tradition, had become unpopular. So, in the representative buildings built in that period, it was used in the interior layer coated by stone cladding. However, towards the middle of the century, these two materials returned to prominence with the construction of Les Halles (covered markets) of Paris by Víctor Baltard commissioned by Haussmann ${ }^{11}$.

From that moment, Jean Charles Alphand, Haussmann's usual collaborator, built numerous buildings popularizing this combination that was brought to Spain with the construction of the Almería station being a novelty in the construction of railway stations. However, other contemporaneous and more relevant stations, such as Valladolid Campo Grande (1895), Sevilla Plaza de

11 See Benévolo, 2007, pp. 122-123. In 1971 began its demolition for the location of a commuter station, Châtelet-Les Halles, and a large shopping center, Forum des Halles. 
Armas (1901) or Valencia Alameda (1902) did not bring any novelty to the architecture of the railway stations.

Also, the use of terracotta 12 was experiencing a revival in those years used for the decoration of facades and it was also brought to the Almería station both in the pilasters that flank the main body and on the parapets of the first-floor balconies and ground floor windows (Figure 10), as, finally, in the decoration of the roof pinnacles (Campbell, 2003, pp. 222-223).

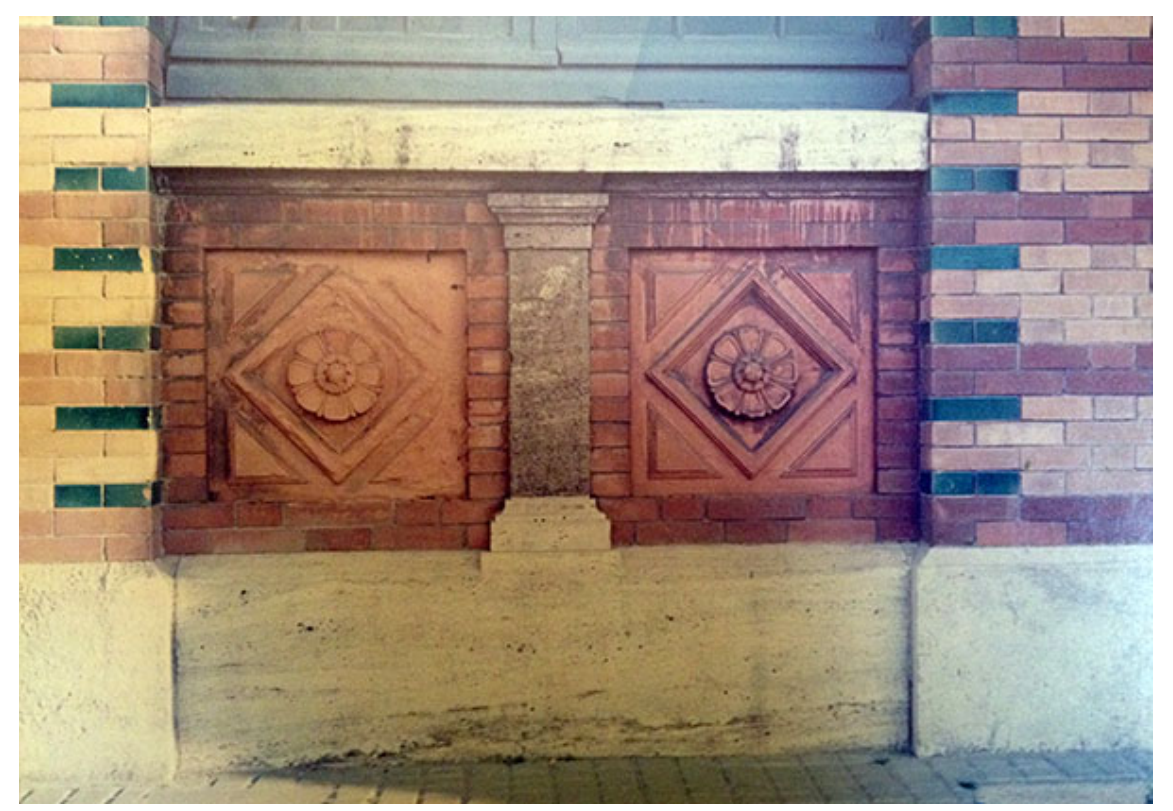

Figure 10. Terracotta decorations. Source: Morales Medina, 1987.

Regarding the use of brick, it is considered relevant to make a brief historical contextualization of its use in Spain since it is the basis of the hypothesis that we hold about the material nature of the original roof balustrade.

The brick began to be industrialized in Spain in the mid-nineteenth century, although it should be specified that it was solid brick. The visual analysis of pieces from the Almería station shows that they were already industrialized pieces due to the uniformity in sizes and the homogeneity in colour, since the traditional, handcrafted construction, favoured differences both in sizes and in coloration (Campbell, 2003, pp. 202-208).

The origin of the lightened brick dates to the patents of Caleb Hitch in 1828 that manufactured in his factory in Ware (England). The so-called hitch bricks, bricks with holes in the broad face, were presented at the Great Exhibition of 1851 in London13. These were perforated bricks with three perforations, like those existing in the roof railing found when the rehabilitation project was faced in 1987 (Figure 11) ${ }^{14}$.

In 1900 there were a lot of solid and hollow brick patents in Europe and much more in the United States. But while the United States advanced by adopting the new techniques, England and northern Europe remained firmly anchored in the tradition of solid brick using even manual moulding techniques until the 20th century (Campbell, 2003, pp. 218-219).

\footnotetext{
${ }^{12}$ A hard, fired clay, reddish-brown in colour when unglazed, used for architectural facing and ornaments, tile units and pottery.

13 The first of a series of international exhibitions that took place during the second half of the 19th century and the first third of the 20th. This one from London was called Great Exhibition of the Works of Industry of all Nations.

14 It is necessary to distinguish between perforated bricks, with cavities on the broad face, and hole bricks, with perforations in the shorter face.
} 


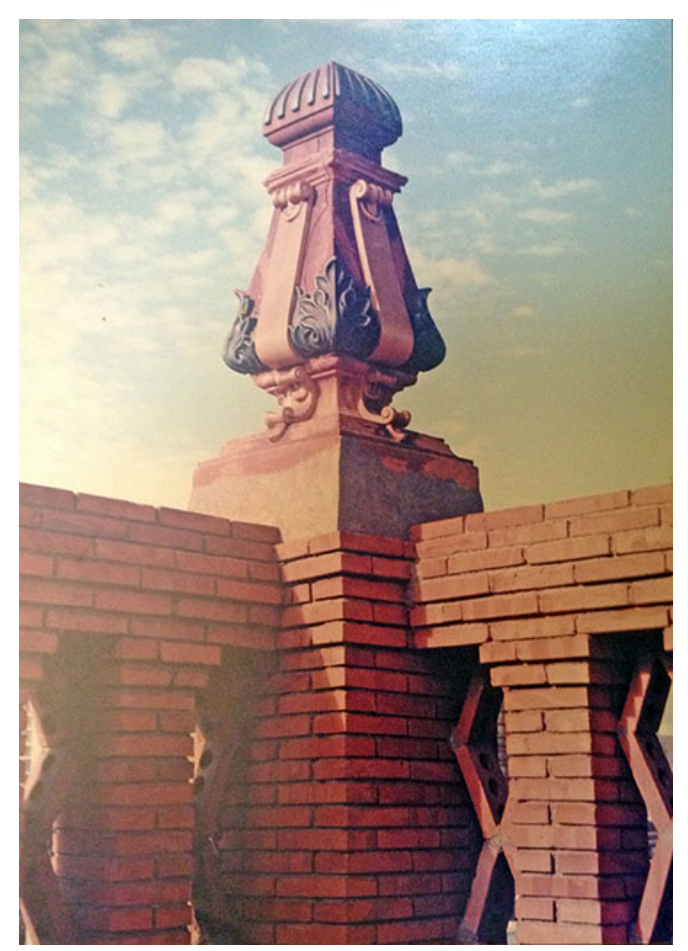

Figure 11. View of the roof balustrade in 1987. Source: Morales Medina, 1987.
The case of Spain is even worse in terms of delay. According to Reverté, in Spain, until 1936 there was no import of hollow, hourdis or perforated bricks, due to being construction innovations not yet accepted in our country where the brick industry was still manufacturing the uneconomic solid brick (Marcos y Bausá, Ricardo, 1879, pp. 49-57). Corroborating this information, Ricardo Marcos in his Manual del albañil describes the brick manufacturing process in Madrid, referring only to the use of brick racks and, therefore, to the manufacture of solid brick. On the other hand, Florencio Ger in his Tratado de construcción already includes the description of hollow brick like an original product of the pottery tradition destinated for lightening of constructions or to avoid dampness (Ger y Lóbez, 1898, p. 27).

We must emphasize that the distinction between perforated and hollow brick was after the construction of the Almería station and until then, the construction treaties described do not mention the perforated bricks. Therefore, when the 1987 rehabilitation project describes the roof handrail referring to the existence of perforated brick in its composition, it is impossible that it was the original handrail.

It is convenient to add that the constructive change towards the use of the hollow or perforated brick in walls comes from the revolution supposed by the independence of the structural system with the closure one and that took place at the beginning of the 20th century, also after the construction of the station, where the facade still held both the load-bearing and the enclosure requirements.

\subsubsection{The materiality of the project}

With regard to the foundations and structure, in the original project of 1892 , the foundations were located at $6.70 \mathrm{~m}$ of average depth and consisted of a column of poor concrete of $3.50 \mathrm{~m}$ height covered by another layer of hydraulic lime concrete "from the factory of Le Teil "(France) $1 \mathrm{~m}$ thick, which supported the masonry walls that measure $2.70 \mathrm{~m}$ height up to the ground level having an approximate thickness of $0,50 \mathrm{~m}$.

The rest of the perimeter walls are load-bearing walls with a thickness of $0.50 \mathrm{~m}$ and are apparently composed, after analysis of the project, of three layers: interior layer, internal filled chamber and exterior layer based on brick face. The baseboards and cornices are made of limestone of two varieties: hard for pilasters and baseboards and soft for cornices and entablature. The internal partitions, also loading walls, have a thickness of $35 \mathrm{~cm}$.

Thus, the structural configuration presents the typical arrangement of the structures designed based on load-bearing walls composed of orthogonal cells that combine main walls with tie walls.

On the other hand, the cross-section allows seeing the composition of the slabs, which have an approximate thickness of $35 \mathrm{~cm}$ and are composed of metallic beams I-shape with $80 \mathrm{~cm}$ spanning light, composed of hollow ceramic pieces. The maximum span length is 6 meters.

The main metal trusses that form the structure of the central body are triangular porches based on lattice beams composed of triangular "L"-shaped steel profiles with stiffeners in the joints running monolithically from the foundation to the ridge. This type of structure is also unique since, on the one hand, it shows a similar structural typology, albeit on a more modest scale, to that of the Galerie des Machines designed by Dutert and Contamin in 1889, reserved for large spaces and thus providing grandeur to the lobby of the station. 
On the other hand, as we pointed out in previous sections, it is the first case of a Spanish station where the passenger lobby openly shows the large metallic structure reserved for the train space. We will have to wait for the extension of the Barcelona-Nord station in 1910 to find a similar case, although note and this adds more value to the Almería station, the notable differences between the size of the cities, Almería and Barcelona, and between the companies that built them: the powerful North of the Péréires Brothers and the ambitious South of Bosch, respectively.

The variant of the structure has rigid joints in both the base and the ridge. It consists of two porticos left in view on both facades and a third intermediate portico. In the transverse direction, beams in lattice type Pratt of $50 \mathrm{~cm}$ thickness are arranged. The tying beams are disposed of every $2.50 \mathrm{~m}$, alternating with the main porticos. The joints are projected riveted and, finally, highlights the fine ornamental work done in the main metal trusses.

In regards to the facades, their composition is made of: baseboards and corner reinforcements are made of "hard" limestone (elements not decorated), the exterior layer made of face brick with Flemish brickwork, widely used in Spanish Mudejar architecture, combining natural pieces with yellow or green glazed ones. The result is an interesting material contrast between these neoMudejar walls and the great curtain wall of steel and glass in the central body done in a French way.

A great variety is observed in the execution of brick archivolts. In the headwalls, they are executed with thicknesses of 1.5 pieces, alternating the joints and decorated with glazed ceramic moulding. In the main facade, the same scheme is repeated, except in the three main doors of the central body where the brick protagonism is given to the fine work of locksmithing.

The rear facade is executed in a simpler way. In this case, both the arches of the ground floor and those of the upper floor, are made with archivolts of a piece of thickness alternating joints. In the three main doors, what is executed in the main facade is repeated.

The double-sided roof of the central body is finished with zinc sheet, and a flat roof is disposed on the lateral bodies finished in ceramic tile. On the other hand, the interior non-structural partitions are executed on brick walls on U-shaped profiles anchored to the slab and, finally, the interior coverings are plastered while the exterior, only on the rear facade, is plastered with a bushhammered finish.

Regarding the original railing, following our hypothesis, it was executed in neoclassical style as it is deduced from the analysis of the elevations and sections contained in the original project. Hypothetically, after analyzing the carved mouldings found in entablatures or cornices, it can be assumed that it was built with the same soft limestone used in other parts of the facade. On the other hand, in the roof pinnacles, the coat of arms of the main towns of the railway line was represented 15 .

Another option with respect to the original materiality of the roof railing that would also admit the moulding of the neoclassical style represented in the original project found out after the analysis of old photography, is that all the pieces, of neoclassical style, were finished with terracotta following the same pattern as the rest of railings and parapets that appear on the main facade and on the lateral ones. This materiality would fit with the pinnacles ones finished in terracotta and where the softness of the material allows more easily the representation in detail of the coat of arms of the main cities of the line described previously. In any case, there is no reference to a handrail executed in Moorish style in the original project or in the oldest photographs.

Perhaps the original balustrade disappeared in the bombing of 1937, due to the Spanish Civil War, and could be reconstructed before 1971 with perforated brick and in Moorish style, since it can be seen in some of the cinematographic scenes of the film "Agáchate maldito" by Sergio Leone, shot

\footnotetext{
15 In alphabetical order: Baeza, Granada, Guadix, Linares, and Úbeda. In the case of Linares, a mining city, it was the end of the line and in the case of Guadix, it was an important intermediate point. The mention of Granada was due to the ambition of the company, which would end up building a branch to it in 1904 and, finally, the mention of Baeza and Úbeda is since in the original project of Fives Lille of 1892 it included the passage through these two cities, which in the subsequent reforms were discarded, to shorten the layout and make the exploitation profitable. See Cuéllar, 2003, pp. 200-201.
}

(C) Labor \& Engenho, Campinas [SP] Brasil, v.12, n.3, p.306-330, jul./set. 2018. 
that year in Almería station. This handrail is referred to in the 1987 renovation project whose literal description is that it was executed with perforated ceramic brick and glazed elements. This information is key to determine that the original railing was not restored because, as we have explained previously, at the time of construction of the station, there was no perforated brick technology in Spain. Therefore, the handrail that describes the remodelling project was built between 1936 and 1971 although we do not have sources that confirm it convincingly.

With regard to the pavements, on the ground floor there are three types: cement pavement for the departure and arrival halls and for the left-wing staircase access; marble pavement, in white and grey checkerboard, for the offices of the head of the station, police station and waiting room of 2nd and 3rd class and, finally, ceramic flooring for the rest of the rooms on the ground floor.

The layout of the cement pavement is in the perimeter strip, pieces arranged on the bias, decorative frieze and central area with pieces arranged squarely. In the marble flooring, the design arranges the pieces on the bias for the central area and the square ones for the perimeter trip alternating the first design described. The ceramic flooring also has a perimeter strip, although it does not detail the layout of the pieces. In Spain, the use of ceramic polychrome pavements became popular since 1851 and later, the hydraulic mosaic was added, obtained by pressing cement mortar, becoming the most common pavement in the Spanish construction of the turn of the century. This type of cement pavement is the one found in the arrivals, and departures lobbies and in the stairs of the station. Note the successful selection of pavements regarding their functionality, reserving the hardest ones for the busiest areas but without neglecting the aesthetic function.

Cement pavements were what is known as hydraulic tile. Famous in Andalusia since the beginning of the twentieth century are the factories of the Torres López and López Luque brothers. This technique is of French origin and had a great impact on the flooring design since the Universal Exhibition of Paris in 1867. The great technical breakthrough lay in the no need to cook the pieces that were executed by pressing and subsequent setting and hardening of the cement. The motifs used to be geometric or vegetal and the existence of frieze was usual (Castillo Martínez, 2016, p. 30).

Exhaustive modulation in the layout of the pavements detailing the dimensions of the pieces, the corner pieces and the special ones, which required a careful replanning.

For the upper floor, the graphics of the original project suggest that there was ceramic flooring and, although it does not detail the modulation and type of pieces, it does mark those rooms that must have a single or double border, as is the case of the living room, dining room and main room of the house intended for the station manager. The part of the offices, on the left wing, only has a perimeter strip in all rooms. So, through the design and the materiality of the pavements, the category of the space also was shown. Unfortunately, as it appears in the 1987 modernization project, most of these floors were covered.

With regard to interior carpentry, the project details show three types of the interior door: one-step door, opaque simple; double-leaf doors, composed of solid wooden panelled baseboard and glass top and, finally, bigger and finer design doors, reserved for public attention rooms. Their overdoor is formed by wooden profiles framed with terracotta panels decorated with geometric motifs of Arabic reminiscences. The arrangement in the walls of the first two types of door is at the same level of the wall while the third type of door is arranged a third set back by executing some flare in the wall in a more sophisticated solution.

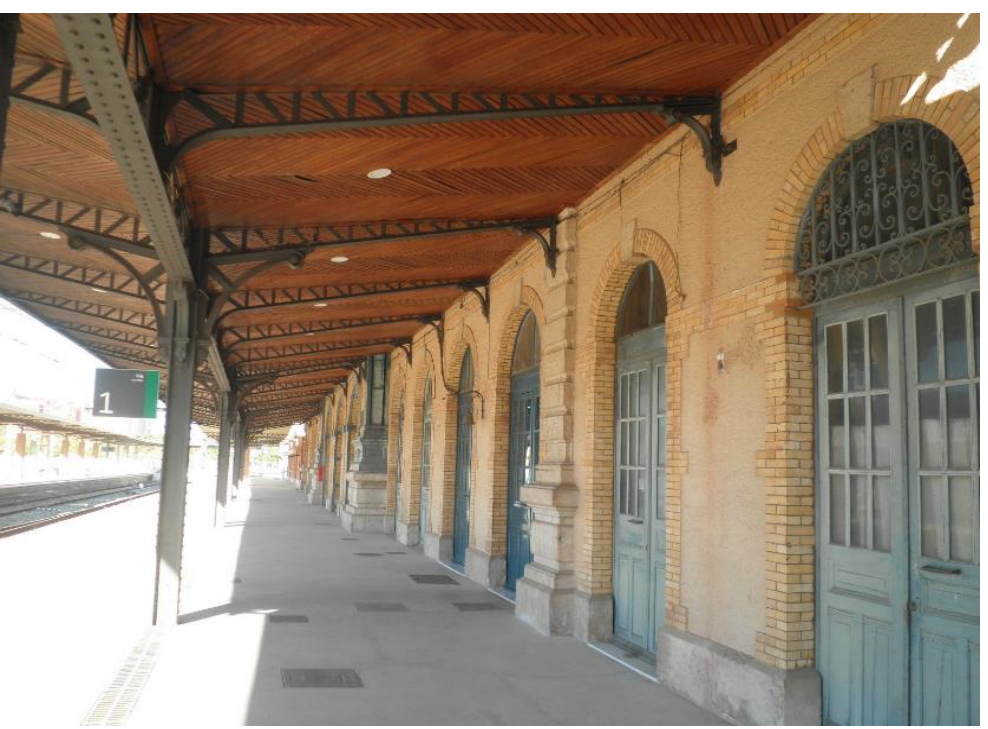

Figure 12. Rear facade canopy. Source: Morales Medina, 1987. 
There are also wooden panelled baseboards and coffered ceiling in the most important rooms. As was mentioned for the pavements, the work of the wood also allows differentiating the category of the room. According to the remodelling project of 1987, the wood used in all the interior carpentry was high-quality pine. A very abundant type of wood in Spain.

The exterior carpentry is also configured in wood based on panelled baseboards and glass top in the doors and conventional design for the windows. Only the three main doors mentioned before are projected in finely decorated iron.

Regarding the exterior canopies, the one located on the rear facade is designed by longitudinal trusses with cross-shaped diagonals and transverse Pratt type trusses in cantilever of variable section. Both with scarce decoration with reinforcing and rivets left in view expressing the nature of the material. The intrados of the cover board is made with V-shape wooden elements (Figure 12).

However, the marquee that is arranged on the main facade over the three main doors is composed of I-shaped profiles, also simply decorated but the cover board is made of reinforced glass. The gutters to collect rainwater were camouflaged in the part of the encounter with the facade so the slope went towards the facade.

In the original project are delicately drawn the details of all the metallic decoration of the facade, the mouldings and reinforcements of "hard stone", the interior wooden partitions and the panelled baseboards, the coffered ceilings (Figure 13), the different types of brick in the exterior walls, the pipes, the partitions, the foundation anchoring plates, etc. Therefore, it is a project that contains a high level of detail and information and that constitutes an important element as documentary heritage to be preserved. According to the remodelling project of 1987, the prescriptions contained in it were faithfully followed.

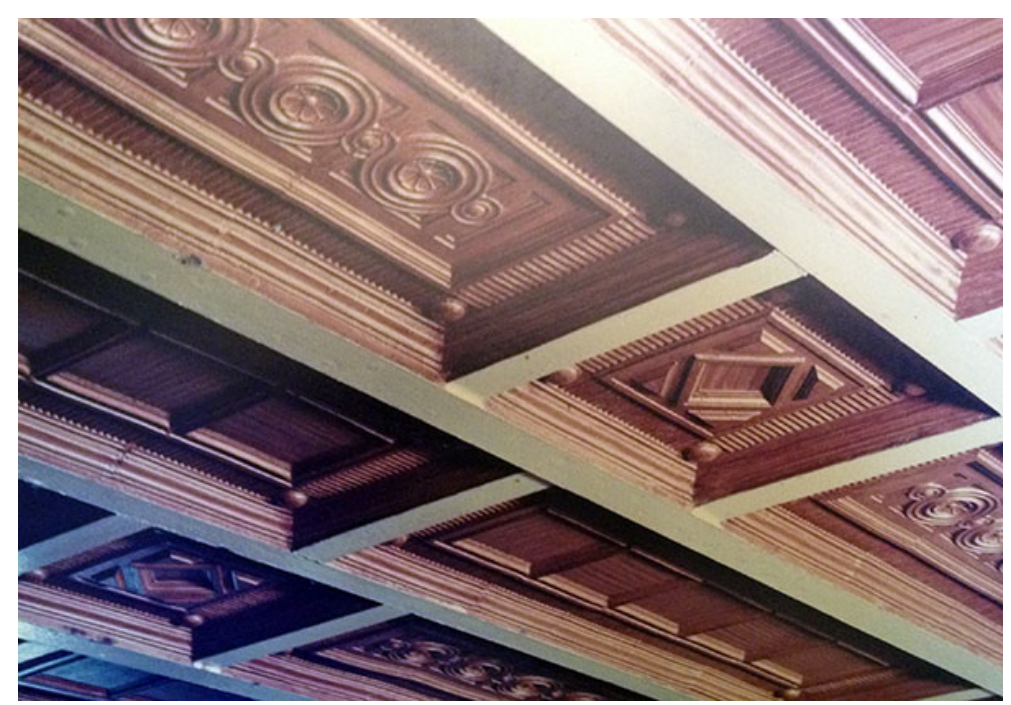

Regarding the polychromy, the colours used in the facade are the typical reddish of the unglazed bricks combined with the green or yellow of the glazed pieces. Also, the mouldings that frame the arches or the vegetal decoration are made in glazed green ceramics but combined with reddish colours in the rosettes or geometrics decorative pieces.

\subsubsection{Added values. Constructive sincerity}

The travellers building of the Almería station, in addition to the richness described in proportions as well as in style and materiality, presents, from the point of view of construction, the added value of didactically expressing aspects related to the nature of the different materials and its structural behaviour.

Thus, in the construction of the arches, the architect is concerned with executing the main pieces, key and springer, in a more resistant material, "hard" limestone, which allows the geometry that the piece requires without cuts or joints. Also, the impost, another key element, in the main and lateral facades, is executed in the same natural stone. Regarding the windows jambs in the main facade, except for those of the central body to which we will refer later, the subtlety of reinforcement is introduced by glazed ceramic pieces, which serve as decoration, but fundamentally preserve these weaker points much better against deterioration because the glaze provides greater resistance to the surface of the pieces. 
In the rear facade, all this is simplified, but the scheme is still recreated with the arrangement of keys and springers in hard limestone and, in this case, as the facade is not executed with face bricks, a brick strip simulating the impost and the archivolts gives reinforcement to both jambs and curved lintels of the hollows. That is to say, also in this facade, the architect is concerned in showing the constructively key parts.

The use of corner reinforcements by stone padding is a widely used resource that, in this case, obeys to compositional reasons to preserve the classic scheme but at the same time, protects these weak points.

The entablature is executed in the whole perimeter composed by a great cornice flown for protection of the facades. The decorated friezes are reserved only for the main and lateral facades, showing the reading that the element, cornice plus entablature, is completely necessary following the classical composition criteria -the cornice flown alone would serve as protection to the walls- but the decoration is accessory.

Special mention deserves the central body. Here the architect breaks in a subtle way with the classic style and insinuates very novel questions for the time, such as the replacement of the decorated stone that we detailed previously, by simple imposts, jambs and iron arches without any decoration even inside the lobby despite being the most noble part of the building and usually covered with materials considered noble in that time such as marbles, natural stone, fine woods, etc. but never steel without any decoration. So, the main access presents the new material as it is, in its nature, also removing the structural role to the brick and stone with the detail of removing the stone plinth in this area. Something similar happens with the two large columns that flank the central body, although here the material is decorated. In this case, although with the mask of classic composition and decoration because it is shown to the urban space, the decomposition of the solid, stone pilaster in two metal pilasters with rivets seen seems to imply that the properties of the new material allow new structures much lighter and that these buildings should show.

In a subtle way, it is, in short, showing the city a large metal column without decoration leaving unions rivets seen implying with it a great modernity that is not possible to contemplate in any other of the large stations built in Spain until that moment. Therefore, showing the metallic structure and the glazed front only had been built the stations of: Málaga Andaluces (1865), where the metallic body is independent of the masonry ones; Madrid Delicias (1880), where a more classic solution is shown showing the uprights of the glass front as if they were foundry columns; and Madrid Atocha (1892), where the arches that make up the truss are shown, but widely decorated.

\section{Renovations carried out}

The railway operation is an activity in continuous evolution that subjects its facilities to constant transformations, being necessary numerous reforms that do not keep the buildings in their original state. In fact, most of the railway stations in the world continue to operate with their original buildings but with the necessary changes or modifications. Perhaps the Spanish case is unique since many new railway stations have been built associated with the arrival and expansion of highspeed rail. But in many European cities, for example, the historic buildings of the Gare du Nord, Lyon or Est in Paris, or Sant Pancras, London Bridge or King Cross station, continue to be used for modern rail service. Of course, its architecture and services have been adapted to the reality of current use.

It is thus easy to understand that any railway station is conserved in the same state in which it was built, although the intensity of the changes is variable. In the case of Almería station, works and modifications have been constant from the moment of its construction, but almost all of them of little importance reason why, in general lines, the integrity of the building has been maintained from its origin. Both in regard to the complementary facilities that make up the entire railway station, understood in its broadest sense, as in the case of the historic building, object of study, have been preserved in a similar state to the original. 


\subsection{Renovations of the first half of the 20th century}

The first major reform of which we have evidence occurred in 1914, although in the previous year a reform project was presented. This project was initially rejected by the 4th Technical and Administrative Division of Railways, which was the Spanish public organism in charge of supervising the interventions that were made in the services and facilities of the railway companies. The 1913 project was signed by the engineer Enrique Paniagua, employee of the company, who, in summary, proposed transforming some of the offices into housing for the staff, relocating some services of the operation in other annexed buildings. The attempt was rejected by the chief engineer of the division, José Molero Levenfeld, who ordered paralyzed the works urgently because they were converting the station into "a house of neighbours for saving a few pesetas16."

Then, the company was forced to redo the project in this case carried out by the engineer José Iribarren, although the modifications on the previous one were minimal. However, the official report indicates that the railway's division requests were attended.17

The deep economic crisis of the company made the reforms were minimal. Thus, in what is known until today, after the economic agreements registered with the Andaluces Railway Company, which absorbed the South Company provisionally in 1916 and definitively in 1929, the new owner decided to face an important reform that would allow offering services more in line with the times (Cuéllar, 2003, pp. 221-222).

The new reform project was presented in 193018, and was planned to meet the growing traffic demand. The works to be carried out were divided between works subject to the exploitation service and works destined to the service of material and traction. The first included the extension of roads, the reform of the travellers building, the construction of freight docks, the expansion of platforms, the closing walls, the paving of warehouses, the new seawage collector, and the adaptation of the fourth bedroom for trains gangs.

With regard to the works planned for the material and traction service, the construction of a boiler making and assembly workshop, a workshop for car repair, a ferry bridge pit, fire pits, new premises for the workshop and a shed for the hydraulic jack were carried out. The set of works was expected to be completed within 20 months and its cost was 1.8 million pesetas at the time. The engineer who designed the project was Antonio Rivera and was approved by the chief engineer of the 4th Technical and Administrative Division of Railways, José Molero, who we have already seen involved in the previous works.

As noted above, a small part of the project was intended for the partial reform of the passenger building:

"The building in which the different units are installed is of modern construction, it is in a good state of preservation and the modification that is projected consists only in providing it with a canteen-café for the comfort of the travellers who will be able to find in it the indispensable to meet the small refreshment needs" 19.

Finally, the strong economic crisis of the Andalusian company (Cuéllar, 2015), that would lead to its seizure by the State in May 1936 meant that none of these works began in this period. The company alleged that the lack of credit made impossible to start with the approved project works for the Almería station (Andaluces Railway Company report, 1933, p. 47).

\footnotetext{
${ }^{16}$ AHF, A-107-10, Modifications of the passenger building of the Almería station. Line from Linares to Almería,1913.

"Peseta": original name of the official Spanish currency used then and until the entry of the euro.

17 AHF, A-142-15, Almería station, 1914.

18 Administration General Archive (AGA), (4)102, 24/08622, Project of renovations and improvements in the Almería station. Andaluces Railway Company, 1930.

${ }^{19}$ AGA, (4)102, 24/08622, Project of renovations and improvements in the Almería station. Andaluces Railway Company, 1930.
} 
As it is known, the Civil War had a great impact in the city of Almería, being bombed several times, since it remained in the Republican zone until the end of the conflict. Among these attacks was especially virulent the one produced on May 31, 1937, by the German fleet, causing serious damage to the passenger building of the railway station. It is assumed that this was the moment when the most important damages occur in the upper part of the building destroying the original balustrade, as well as some pinnacles with their corresponding coats of arms, previously detailed.

\subsection{Renovations of the second half of the 20th century}

This suggests that, despite not having been able to locate other reform projects until 1987, and since the 1930 proposal was pending, between the 1940s and the 1960s, other reform works had to be carried out determining the distribution and uses of the building found in the 1987 reform project such as, for example, the installation of a canteen inside the building.

The 1987 reform project was the most important one carried out in the travellers building of the Almería railway station, being part of the "Modernization and Station Equipment Plan" launched by RENFE in the 80s. The aforementioned project is titled "Modernization of the railway station of Almería. Restoration and remodelling of the travellers building and construction of canteen and roundabout", was signed by the architect Antonio Morales Medina in October 1987 and was supervised by the Head of Building of the Plan of Stations of RENFE. It is interesting to note that the aforementioned project does include a historical review of the building but does not mention the initiation of the procedure to declare the building as an element of the Spanish cultural heritage that had taken place barely two years before, as we explain later.

This project was executed between 1988 and 1991 and had as objectives the treatment of the existing pathologies in the building, the interior reorganization of the spaces in relation to the existing uses, the recovery of the waiting room in the space that was occupied by the aforementioned canteen, and, finally, the partial arrangement of the exterior space with the demolition of the toilets and the construction in its place of the new canteen surrounded by a garden area (Morales Medina, 1987).

Regarding the restoration and partial remodelling of the travellers building, the project's report describes the current state of the roof balustrade stating that it is not the original one 20 . Strictly speaking, the handrail found at the time of drafting the project, consisting of columns and a kind of lattice made of perforated bricks, should not be called a baluster, but a handrail since it is not composed of moulded elements. About the pinnacles, the project highlights the disappearance of some without being able to identify which ones.

It also describes the current state of cornices, entablatures, pilasters, and baseboards distinguishing between soft and hard limestone. As expected, it indicates a lower deterioration in the hard limestone and its use in key elements for good preservation of the building: such as baseboard (to avoid humidity by capillarity towards the brick walls), corner cushions or key of the arches. Regarding the state of the walls and decorations indicates that they are in good condition.

The elements of the iron structure only present superficial damage and the cast iron decorations some loss of mouldings. Regarding the access doors, the project states that they are well preserved. The I-shape steel profiles of the slabs present some oxidation and corrosion although only the first floor is inspected but not the roof one which is expected to be more deteriorated. In any case, it does not refer to a generalized bad state. The project proposes, at least for the first-floor slab, the mechanical cleaning of oxides in an exhaustive way, as well as the reinforcement with a thin layer of reinforced concrete. On the roof slab, it is unknown if any type of reinforcement was carried out.

Regarding carpentry and wood elements, the project describes a good condition of the main elements for being pine of good quality and deterioration in secondary elements especially those on the ground floor. The project also highlights unfortunate actions carried out in these carpentry elements, in the replacement of downspouts, in the modification of interior partitions

\footnotetext{
20 The use of the word balustrade or baluster refers to the fact that it would be constituted by elements, usually of
} stone or wood, moulded or turned. 
and in the execution of false ceilings and intermediate slabs covering the coffered ceiling and the polychrome foundry pillars that existed in the old waiting room. The pavements have also been replaced and it is only possible to observe in the then secretary's office, checkerboard based on pieces of white and grey marble, although very deteriorated. The roof pavement is based on ceramic tile and is in good condition.

Thus, the most relevant conclusion reached by the architect in charge of the rehabilitation, Mr. Morales, about the state of the building is the possibility of almost complete recovery of the original elements, as well as its reliable documentation. In this way, the actions to be carried out in the passenger building focus on the strict correction of pathologies and replacement of missing elements, the demolition of foreign elements and the reorganization of spaces and uses of the ground floor with criteria to recover those original uses as far as possible.

It is justified at that time that, inevitably, new facilities must be incorporated to update the building that cannot be analyzed due to the lack of documentation, but it is worth noting that the starting point of the project is both the analysis of the original project as well as the historical context regarding the company and the construction of stations in that period. We consider that this previous study of the existing documentation as well as the previous analysis of the building should be exhaustive, and it is fundamental for the identification of original elements and the adoption of good performance criteria. In short, it is about understanding the logic of the existing building without trying to superimpose any different discourse (Solà-Morales, 2001).

The restoration of the damaged elements of natural stone is projected by sewing and sealing existing cracks. The replacement of cornices and entablatures is made by taking moulds obtained from those parts not deteriorated of the aforementioned elements, filled with epoxy mortar and carved wherever it is required.

The replacement of missing elements is based on the criterion of "copy of the original". It would be the case of the missing pinnacles executed by filling moulds with epoxy resin identical to the preexisting ones, the stone elements, the ceramic decorations or the decorative metallic elements. It is prescribed in the project that elements that differ greatly from the original will not be accepted.

On the other hand, it is unknown if the new facilities that the project contemplates have maintained the original artistic character of the elements through which they run or on which they are located following the basic precepts of the Athens Charter (1931). For instance, the restitution of the downspouts to their original location by the interior of the pilasters based on downpipes of cast iron of identical section to the original and with the same anchoring system would follow the basic precept described. If there were PVC or fiber cement downspouts left in view on the facade as they were at the time of the 1987 intervention, the character and perception of the building would have been significantly altered. Hence, the importance of previous documentation and analysis as a guarantee of the authenticity's safeguard.

However, beyond the bad state found, the lack of justification for the complete replacement of pavements is missed as well as the criteria followed to make the substitution with materials and disposition completely external to the original. The same happens with part of the coatings or partitions and carpentry arranged. It is not a matter of imitating, but not of placing completely dissonant elements.

A few months after completing this reform, a mosaic with railway allegories made by the local artist Luis Cañadas (1928-2013) was incorporated into the main lobby (Illustration 14). It represents railway allegories and elements of the Almería landscape such as the railway viaduct over the Andarax river in Santa Fe-Alhama or the typical terraces of the Mediterranean white-washed houses 21 .

Finally, since this last intervention, and after the almost complete closure of the building in May 2000 , no actions have been carried out in the building, beyond small maintenance interventions.

${ }^{21}$ About this mosaic and the work of Luis Cañadas, see Durán Díaz, 2013.

(C) Labor \& Engenho, Campinas [SP] Brasil, v.12, n.3, p.306-330, jul./set. 2018. 


\section{Labor \& Engenho}

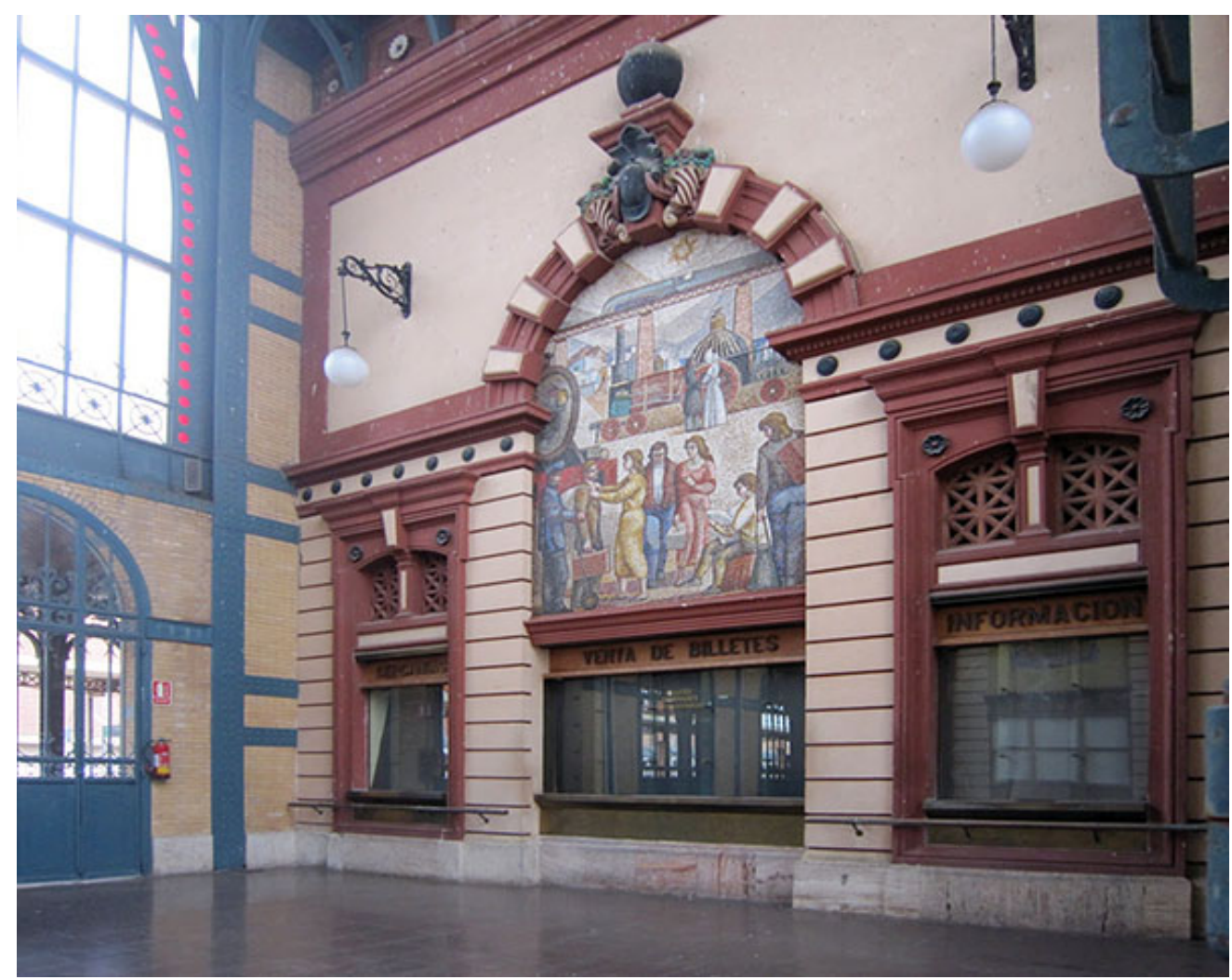

Figure 14. View of the lobby. Detail of Luis Cañadas mosaic. Source: Morales Medina, 1987.

\section{Heritage situation and building protection}

Regarding the patrimonial protection of the building, we must point out that the procedure of declaration of historic-artistic monument was started by resolution of April 1st, 1985 of the Fine Arts Administrative Office of the "Junta de Andalucía", and since that, according to the provisions of the legislation, all the works that were to be carried out in the building had to have the prior approval of the aforementioned state organism ${ }^{22}$.

We emphasize that, in this procedure, registered in the database of Andalusian monuments, there are numerous errors that have not been corrected since its registration in 1985. On the one hand, it is registered the name of the monument as "Renfe Station", when it would be more appropriate the denomination of "Railway station of Almería". In addition, the authorship of the mosaic is assigned to Francisco Cañadas, and not Luis, as it would be correct, without including the date of its installation either. Finally, referring to the roof railing rebuilt after the Civil War, it is described as a brick balustrade, when, as we have explained previously, it should be referred to as a brick railing23.

On the other hand, as a continuation of the procedure and by resolution of June 15, 2005, of the Fine Arts and Cultural Assets of the Spanish Ministry of Culture Administrative Office, it was agreed to open a period of public information for the declaration of the station as a monument. It is important to indicate that, since the application of the 2003 Rail Sector law, the station belongs to the Spanish Railway Infrastructure Administrator (ADIF) 24.

Despite this, the case started 33 years ago, has not continued until the declaration as a monument of the historic building of the railway station of Almería as would have been logical and

\footnotetext{
22 BOJA, 35, 17-04-1985.

23 https://www.iaph.es/patrimonio-inmueble-andalucia/

24 Previously, the station was assigned to the National Network of Spanish Railways. See ORDEN FOM/2909/2006, of September 19.
} 
desirable. But, because there has not been any complaint about the delay in the procedure, the case remains open pending resolution.

This situation must be solved immediately as it is contrary to the Law and, the owner of the property must protect it as a unique element of the Spanish industrial heritage, as we have discussed in the preceding pages being applicable in future actions, the recommendations of the National Industrial Heritage Plan (2011): Inventory, Study, Master Plan, and Project. In this way, the basic objectives of protection and reuse will be covered to guarantee the survival of the historic building.

In this type of interventions, the Niznhy Tagil Charter for the Industrial Heritage, approved in 2003 by TICCIH (International Committee for the Conservation of Industrial Heritage) defends the values of industrial heritage as a unique testimony of contemporary society and highlights the importance of cataloguing, registration and research of the monuments as well as their legal protection, recommending the following nine precepts about their maintenance and preservation:

1. Preservation of the functional integrity.

2. Evaluation of the possible uses.

3. Preservation in situ.

4. New users are only acceptable if the original patterns of circulation and activity are respected, as well as enabling an area where the previous use is represented.

5. Maintaining the use of the building as a fundamental priority.

6. Interventions must be reversible and have minimal impact.

7. Avoid reconstructions.

8. Register disappeared industrial processes or in danger of disappearing.

9. Promote the conservation of documentary records.

The indications of the international organization are clear and should be respected by all the actors. It is true that the criteria to be taken on the degree of architectural interventions are part of an old and well-known debate among specialists in the preservation of historical and industrial heritage, but from the advice of TICCIH, our recipe is very simple: documentation, minimal interventions, and stable use. This simple recommendation guarantees the maintenance of the essence of the monument and its viability (González Moreno-Navarro, 1999).

\section{Conclusions: debate on the future of the building}

Since the inauguration of the Almería intermodal station in May 2000, the historic building has been left with minimal and private railway use, since only the circulation manager's office is inside. No one since then has been able to pass through the imposing lobby losing people in addition to the use, the enjoyment of the monument.

Since 2000, the building has remained closed and, except very few occasions for a public event, it remains in that way today. Its closure, its inactivity, has caused a logical deterioration that makes advisable major renovations since its maintenance has been minimal for three decades.

In this context, the wide debate generated in the Almería society as a result of the delay in the construction of the scheduled high-speed line between Murcia and Almería, and the problems of exploitation of the conventional network, both with the long-distance service with Madrid as with the regional service with Granada and Seville, has also placed the focus on the historic building being now the object of vindication as a symbol of the necessary intervention of public administrations in the improvement of the railway in Almería.

Regarding the architectural interventions carried out in the travellers building of the station, we conclude that they have been unfortunate. If it can be demonstrated, the replacement of the roof balustrade with the brick railing changing the concept, harmony or overall image of the building, would be the most flagrant intervention suffered outside the building. From the interior, we have already described substantial changes of pavements or coatings among others, that have altered the configuration and the perception of the building forever. In short, actions carried out without an exhaustive prior analysis, without discussion or shared criteria and of course without 
understanding the logic of the building as mentioned above, and without thinking about the heritage consideration. Any intervention can be able to keep both the identity of the building and the environment 25 .

These interventions are in the line of action of those years where the concept of heritage was restricted to some ecclesiastical or noble building and where the concept of industrial heritage was not even imagined. The most serious thing is that despite the passage of time and the advances and theories of heritage conservation, nothing has been achieved. The initiation of the procedure for the monument declaration was achieved, but neither was completed nor materialized in the building. However, the next interventions may involve a radical trend change and an enhancement of the building as a unique element in the Spanish heritage whose architectural and material values are indisputable.

The future use of the historic building is not a new debate, at all. When the issue was discussed in 2000 after the opening of the new nearby intermodal station, many proposals were raised from different forums (State Administrations, citizen groups, etc). We can summarize that the two basic ideas raised were: firstly, to return the building to its historical railway use for which it has been designed and for which it is still necessary; and secondly, to assign a cultural and recreational use that approximates the building to the city allowing at the same time to be object of an intervention, for, either under municipal or shared management, to give a new function to the monument, guaranteeing its integrity and protection as a historical building.

Whatever the decision taken, the declaration of the monument should be solved and then a detailed inventory of the state of the building should be carried out as well as a complete study of it collecting all the existing information, a master plan of the uses and actions in the monument to finally, before making any project in the building, be clear about the criteria to follow in the way that the travellers building of Almería railway station can remain for many years as a reference for the city.

\section{References}

Aguilar Civera, I. (1988). La estación de ferrocarril, puerta de la ciudad. (Vols. 1-2). Valencia: Universitat de València.

Benévolo, L. (2007). Historia de la arquitectura moderna (8a edición, revisada y ampliada). Barcelona: Editorial Gustavo Gili SL.

Broder, A. (2012). Los ferrocarriles españoles (1854-1913): el gran negocio de los franceses (1a ed). Madrid: Fundación de los Ferrocarriles Españoles.

Campbell, J. W. P. (2003). Brick: a world history. London: Thames \& Hudson.

Cano, J. M. (2007). La Fábrica de la memoria. La reutilización del Patrimonio Arqueológico Industrial como medida de conservación. Antiqvitas, pp. 265-272.

Castillo Martínez, A. (2016). Los catálogos industriales y constructivos: identificación de maquinaria y tipologías en el patrimonio industrial. En I Congreso Internacional de Patrimonio Industrial y de la Obra Pública: Nuevas estrategias en la gestión del Patrimonio Industrial, 2016, pp. 23-34.

Comín, F., Martín Aceña, P., Muñoz Rubio, M., \& Vidal Olivares, J. (1998). 150 años de historia de los ferrocarriles españoles. Madrid: Anaya.

Cordero, R., Menéndez, F. (1978). El sistema ferroviario español. En Los ferrocarriles en España, 1844-1943, Vol. I. El Estado y los ferrocarriles, p. 458. Madrid: Servicio de Estudios del Banco de España.

${ }^{25}$ Ferrari, 2011 p. 9. The author established a procedure for the preservation of the railway heritage. 
Cuadros Trujillo, F. (2015). Laurent Farge y el eclecticismo francés en la estación de ferrocarril de Almería. $P H, n^{\circ} 4,1-23$.

Cuéllar, D. (2003). Transportes y desarrollo en el sureste andaluz (1850-1950): historia económica, empresarial y territorial. Madrid: Fundación de los Ferrocarriles Españoles.

Cuéllar, D. (2011). Ivo Bosch y Puig (1852-1915). En Grandes empresarios andaluces (Antonio Parejo, dir.) (pp. 349-355). Madrid: LID Editorial.

Cuéllar, D. (2015). La Compañía de los Ferrocarriles Andaluces en las décadas de 1920 y 1930. Revista de historia industrial, (60), 137-171.

Cuéllar, D. (2017). El ferrocarril en España, siglos XIX y XX: una visión en el largo plazo. Working Papers in Economic History from Universidad Autónoma de Madrid (Spain), Department of Economic Analysis (Economic Theory and Economic History).

Cuéllar, D., Sánchez Picón, A. (1999). El impacto económico de un ferrocarril periférico. La Compañía de los Caminos de Hierro del Sur de España (1889-1929), pp. 619-643. Madrid: Fundación de los Ferrocarriles Españoles.

Cuéllar, D., Sánchez Picón, A., Bouneau, C. (2012). Catenaria: la electrificación ferroviaria en perspectiva histórica (1a ed). Madrid: Fundación de los Ferrocarriles Españoles.

Durán Díaz, M. D. (2013). Siguiendo los pasos de Luis Cañadas en Almería. Recorrido por sus obras en Instituciones. Almería: Instituto de Estudios Almerienses.

Echenique, F. (1864). Breve reseña de los caminos de hierro. Zaragoza: Imp. y lit. de Agustín Peiró.

Ferrari, M. (2011). Patrimonio ferroviario y desarrollo sostenible en el noroeste argentino. Líneas de intervención. Labor e Engenho, 5(3), pp. 1-19.

Ger y Lóbez, F. (1898). Tratado de construcción civil. (Vols. 1-2). Badajoz: Establecimiento tipográfico «La Minerva Extremeña».

González Fraile, E. (1997). Las arquitecturas del ferrocarril: estación de Valladolid. Universidad de Valladolid, Valladolid.

González Moreno-Navarro, A. (1999). La restauración objetiva (método SCCM de restauración monumental). Barcelona: Diputació de Barcelona.

López García, M. (1986). MZA: historia de sus estaciones. Madrid: Turner.

Marcos y Bausá, Ricardo. (1879). Manual del Albañil (3ª edición). Madrid.

Martínez-Corral, A. (2017). Estación de ferrocarriles de la Compañía de los Caminos de Hierro del Norte en Valencia. Génesis, de la idea al proyecto, de los materiales a la construcción. Madrid: Fundación de los Ferrocarriles Españoles.

Meeks, C. L. V. (1995). The Railroad Station. An Architectural History. (1aa edición, 1956). New York: Dover Publications, Inc.

Morales Medina, A. (1987). Proyecto básico y de ejecución de modernización de la estación de Almería. Restauración y remodelación del edificio de viajeros; construcción de cantina y glorieta. Jefatura de edificación. Gerencia del plan de Estaciones. RENFE.

Navascués, P., Aguilar Civera, I. (1980). Introducción a la arquitectura de las estaciones en España. En Les temps des gares, pp. 137-230. Madrid: Ministerio de Cultura. 
Santos y Ganges, L. (2007). Urbanismo y ferrocarril. La construcción del espacio ferroviario en las ciudades medias españolas. Madrid: Fundación de los Ferrocarriles Españoles.

Santos y Ganges, L. (2008). Ciudades andaluzas y caminos de hierro en la historia: aportaciones desde el urbanismo. En 150 años de ferrocarril en Andalucía: un balance, Vol. II, pp. 721-765. Sevilla: Junta de Andalucía.

Sobrino, J. (2008). La arquitectura ferroviaria en Andalucía. Patrimonio ferroviario y líneas de investigación. En 150 años de ferrocarril en Andalucía: un balance, Vol. II, pp. 823-885. Sevilla: Junta de Andalucía.

Solà-Morales, I. de. (2001). Teorías de la intervención arquitectónica. PH Boletin, (37), pp. 47-52.

Sostres, J. M. (1951). La arquitectura monumental. Revista Nacional de Arquitectura, Mayo (113), pp. 24-27. 